\title{
Effects of aeration intensity as agitation in simple photobioreactors on leptolyngbya (cyanobacteria) growth as biofuel feedstock
}

\author{
Aliff Muhammad Orlando ${ }^{1}$, Sulthan Rafii Ardiansyah ${ }^{1}$, Arif Rahman ${ }^{2}$, Nining Betawati Prihantini $^{1,{ }^{*}}$, and Nasruddin $^{2}$ \\ ${ }^{1}$ Department of Biology, Faculty of Mathematics and Natural Sciences, Universitas Indonesia, 16424, Depok, West Java, Indonesia \\ ${ }^{2}$ Department of Mechanical Engineering, Faculty of Engineering, Universitas Indonesia, 16424, Depok, West Java, Indonesia
}

\begin{abstract}
Indonesia known as a hotspot of biodiversity, including cyanobacteria biodiversity. One member of cyanobacteria (prokaryotic algae) is Leptolyngbya. Leptolyngbya HS-16 is an isolate that had been isolated from hot spring in Red Crater of Gunung Pancar, Sentul, Bogor. As mats-producing microalgae, this strain is a very promising source of Biofuel. Biofuel can be extracted from lipid of microalgal biomass. Bioreactor is a method to encourage the growth of microalgal biomass. To get a best result in growth, agitation must be done, to make sure every single cell of microalgae gets the adequate nutrition. The aeration on simple photobioreactors is set to high and low intensity. The high intensity of aerations average amount are 191 bubble/min, while the low intensity one are 117 bubble/min, with a device that could produce smaller bubble size to reduce the aeration-agitation effect. The research was done to acknowledge the effect of aeration intensity to Leptolygnbya HS-16.
\end{abstract}

\section{Introduction}

There are two types of microalgae, prokaryotic and eukaryotic. One member of prokaryotic microalgae is Leptolyngbya, which belong to cyanobacteria. Cyanobacteria is a group of microorganism that utilize photosynthetic process to produce energy and could live upon an extreme area [1]. They could be found at water or soil, whether as solitaire-living microorganism or forming a symbiotic relationship with plants or lichen-forming fungi. Leptolyngbya is a member of Synechococcales order, one order from Cyanobacteria, which is known for their ability to produce mats [2]. One individual of Leptolyngbya may be 0.5 to 3.2 micrometer in size [3]. Leptolyngbya reproduce by hormogonia, a short-motile filament, that could produce vegetative filaments after a few cell division. In addition to their ability to produce mats and forming filaments for reproduction, Leptolyngbya also known as filamentous algae.

Leptolyngbya HS-16 is an isolate that had been isolated from hot spring in Red Crater of Gunung Pancar, Sentul, Bogor [4]. As mats-producing microalgae, Leptolyngbya was a promising source of biofuel [5]. Biomass from Leptolyngbya could produce lipid and after going through a few process, they could be used as biofuel. Biomass was produced because of growth of the microalgae. Growth requires nutrients as well as another factors, such as light, air and how nutrients are utilized.

A suitable agitation needed, to ensure the growth will run well and evenly [6]. A previous research on suitable agitation on filamentous algae [7] had proven aeration or bubbling, are by far the best methods of agitation to use for filamentous algae. Aeration is one type of agitation to circulate the nutrients provided by the medium, to be put to good use by filamentous algae.

In the recent years, the race to found a new sustainable source for energy had rose. People started to think how to get environmental friendly renewable energy. Microalgae contains lipid ranging in $20-50 \%$, and with that value, they could replace oil palm, since they have ten times lipid productivity per hectare, higher than oil palm [8]. More over, the cultivation of microalgae does not require agricultural land development.

Photobioreactors are another option for industrial microalgal cultivation systems. Open ponds systems may have low capital and low operational costs, but their lack of control on operational conditions and their capability to sustain only low biomass productivity, are their major drawback. On the other side, there are photobioreactors (PBR), that can support higher photosynthetic efficiency, biomass productivity and biomass concentration [9]. Furthermore, we have an options to increase the performance of PBR, like having low cost design and designing the efficient mass and light transfer [10]

\section{Materials and Methods}

\subsection{Medium and Microorganisms}

Medium used are Blue Green 11, recipe obtained from NIES [11] with a few modifications. The medium were made by mixing all the ingredients with Distillated Water, and sterilized by using autoclave, on $121^{\circ} \mathrm{C}$ temperature,

\footnotetext{
* Corresponding author: nining.prihantini@gmail.com
} 
for about 20 minutes. Medium later then were used to make working culture, stock culture, and starter culture. For working culture, $200 \mathrm{~mL}$ culture were inoculated to $400 \mathrm{~mL}$ media, as for starter culture, $200 \mathrm{~mL}$ culture were inoculated to $400 \mathrm{~mL}$ media.

Table 1. Blue Green 11 Recipe

\begin{tabular}{|c|c|c|}
\hline Component & $\begin{array}{c}\text { Stock } \\
\text { Solution } \\
\left(\mathbf{m g} \cdot \mathbf{m L}^{-1}\right)\end{array}$ & Quantity Used \\
\hline Distilled Water & -- & $968.9 \mathrm{~mL}$ \\
\hline $\mathrm{NaNO}_{3}$ & -- & $1.5 \mathrm{~g}$ \\
\hline $\mathrm{MgSO}_{4} \cdot 7 \mathrm{H}_{2} \mathrm{O}$ & 10 & $7.5 \mathrm{~mL}$ \\
\hline $\mathrm{K}_{2} \mathrm{HPO}_{4} \cdot 3 \mathrm{H}_{2} \mathrm{O}$ & 10 & $4 \mathrm{~mL}$ \\
\hline $\mathrm{CaCl}_{2} \cdot 2 \mathrm{H}_{2} \mathrm{O}$ & 10 & $3.6 \mathrm{~mL}$ \\
\hline Citric acid & 1 & $6 \mathrm{~mL}$ \\
\hline $\begin{array}{c}\text { Ferric amonium } \\
\text { citrate }\end{array}$ & 1 & $6 \mathrm{~mL}$ \\
\hline $\mathrm{Na}_{2}$ EDTA-Mg & 1 & $1 \mathrm{~mL}$ \\
\hline $\mathrm{Na}_{2} \mathrm{CO}_{3}$ & 10 & $2 \mathrm{~mL}$ \\
\hline $\begin{array}{l}\text { Trace Metal } \\
\text { Mix }\end{array}$ & $\begin{array}{c}\text { See } \\
\text { following } \\
\text { recipe }\end{array}$ & $1 \mathrm{~mL}$ \\
\hline
\end{tabular}

Table 2. Trace Metal Mix Recipe

\begin{tabular}{|c|c|}
\hline Component & $\begin{array}{c}\text { Stock Solution } \\
\left(\mathbf{m g} \cdot \mathbf{m L}^{-1}\right)\end{array}$ \\
\hline $\mathrm{MnCl}_{2} \cdot 4 \mathrm{H}_{2} \mathrm{O}$ & 10 \\
\hline $\mathrm{ZnSO}_{4} \cdot 7 \mathrm{H}_{2} \mathrm{O}$ & 10 \\
\hline $\mathrm{NaMoO}_{4} \cdot 2 \mathrm{H}_{2} \mathrm{O}$ & 10 \\
\hline $\mathrm{H}_{3} \mathrm{BO}_{3}$ & 10 \\
\hline $\mathrm{CuSO}_{4} \cdot 5 \mathrm{H}_{2} \mathrm{O}$ & 1 \\
\hline $\mathrm{Co}\left(\mathrm{NO}_{3}\right)_{2} \cdot 6 \mathrm{H}_{2} \mathrm{O}$ & 1 \\
\hline
\end{tabular}

Microorganisms used in this research had previously been studied [4]. From the study, Leptolyngbya HS-16 was known could live and grow on temperatures ranging on $35^{\circ} \mathrm{C}$ to $50^{\circ} \mathrm{C}$. Natural habitats for Leptolyngbya HS-16 was warm water body and usually had calm surface.

\subsection{Designing Photobioreactors}

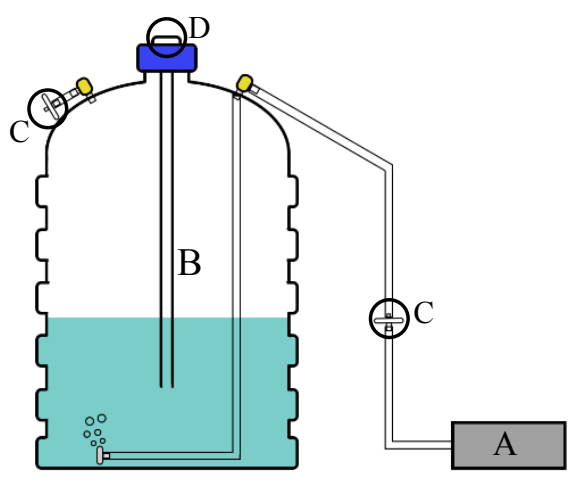

Fig. 1 Initial design for photobioreactors (A : Aerator, B : Acrylic Pipe, C : Sterile Membrane Filter ,D :AClosure)

Photobioreactors are made out of five litre PET, acrylic pipe, clear PVC hose, and a closure from beverages. All the materials were assembled by using liquid nails and glue. As for the light sources, four tubular lamp were added to the system, each two on the opposite side. Two photobioreactors were assembled, the one with low intensity of aeration and another one with high intensity of aeration. Aeration provided to photobioreactors was filtered sterilized with sterile membrane silica 0.22 micron to keep the system sterile from contaminants such as bacteria or fungi.

\subsection{Cultivating and Harvesting}

All measurements were done on 24 hours basis. Starter culture of Leptolyngbya HS-16 was inoculated into photobioreactors with 1:2.5 ratio. The intensity of aeration was set to Low Intensity (117 bubbles/minutes) and High Intensity (191 bubbles/minutes). Photobioreactors were placed inside a room without contact to sun light. Complementary data such as environment temperature, photobioreactors temperature, $\mathrm{pH}$ and light intensity also collected for further research.

Observation were held for 14 days and wet weight were measured 8 times. Sampling for biomass wet weight was done by using $2 \mathrm{~mL}$ eppendorf tube and wet weight could be obtained from subtracting eppendorf tube weight with sample to empty eppendorf tube weight.

\section{Results and Discussion}

\subsection{Leptolyngbya HS-16 Wet Biomass Weight}
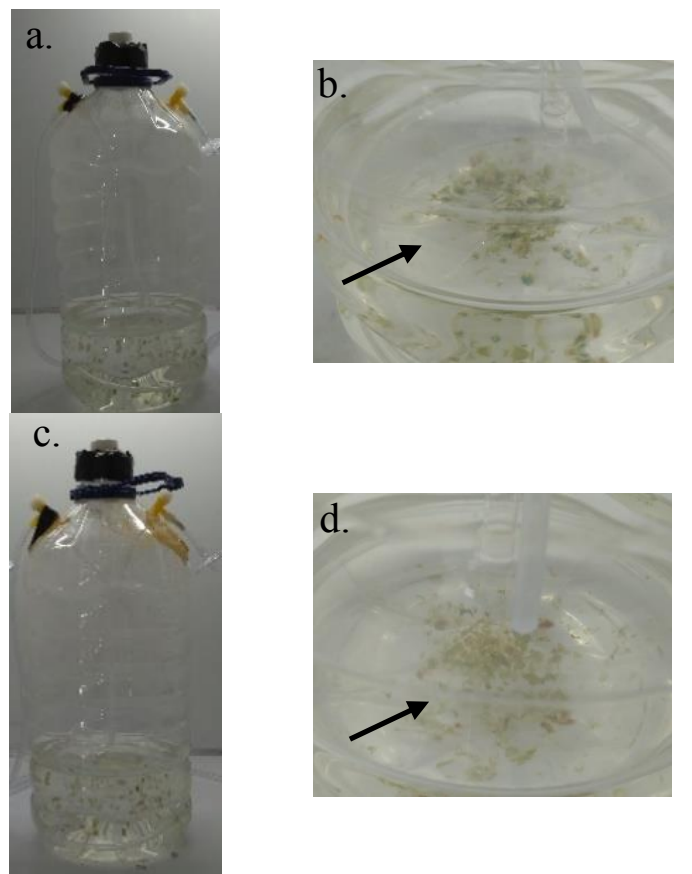

Fig. 2a, b, c, d Photobioreactors on day $3\left(\mathrm{~T}_{2}\right)$ (a : High Intensity PBR, b (arrow) : Culture on High Intensity, c : Low Intensity PBR, d (arrow) : Culture on Low Intensity)

Biomass wet weight of Leptolyngbya HS-16 were obtained by subtracting the weight of eppendorf tube with centrifuged sample with empty eppendorf tube weight.

Wet Weight $=W_{1(\text { tube with sample })}-W_{0(\text { empty tube })}$ 

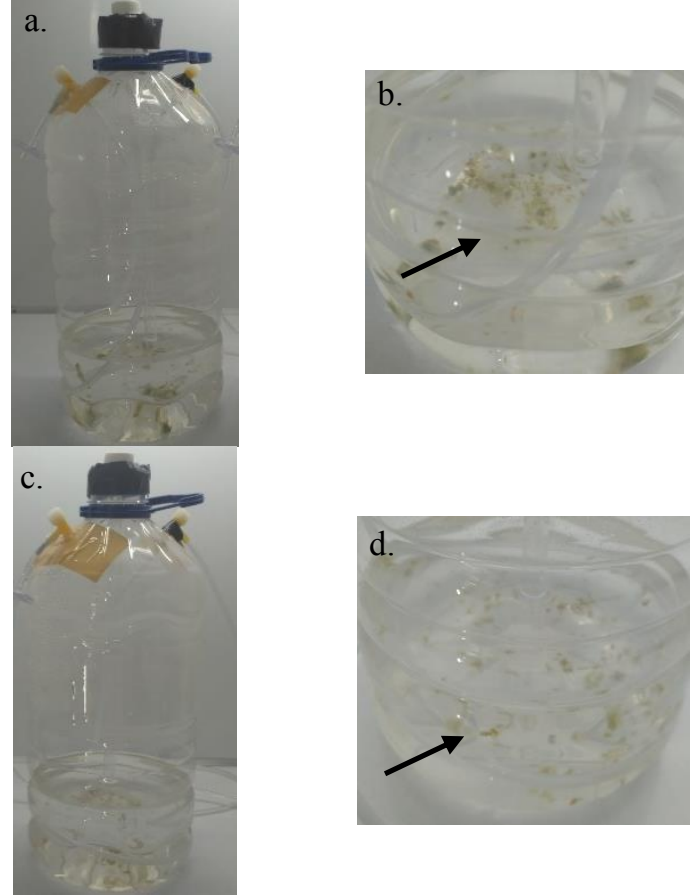

Fig. 3a, b, c, d Photobioreactors on day $11\left(\mathrm{~T}_{10}\right)$ (a : High Intensity PBR, b (arrow) : Culture on High Intensity, c : Low Intensity PBR, d (arrow) : Culture on Low Intensity)

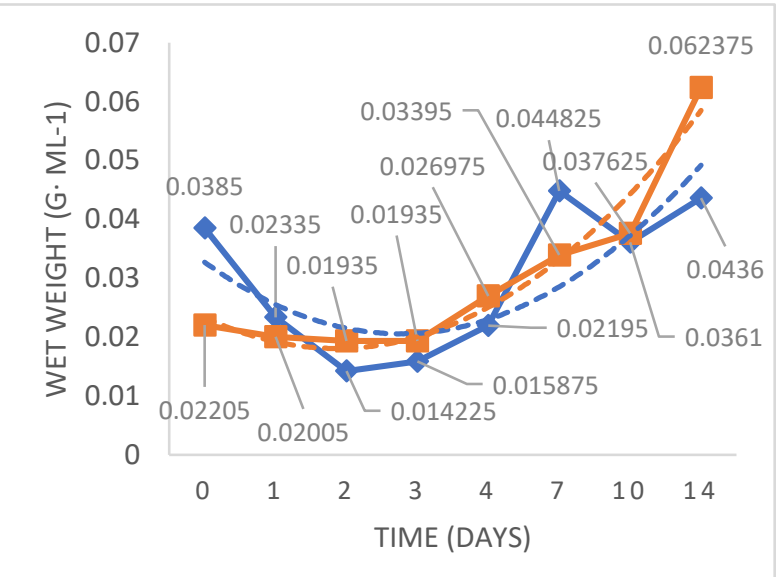

Fig. 4 Average of biomass wet weight (Diamond : High Intesity of Aeration PBR, Square : Low Intensity of Aeration)

From the data shown above, the culture from photobioreactors with high intensity hit the first peak, on day 7 of the observation before declining and hit another peak on day 14, while the other one, photobioreactors with low intensity still showing exponential growth. Also, from the data shown above we can see that, the population from low intensity of aeration have longer log phase, while high intensity aeration, which already hit the peak on day 7 , have shorter log phase.

Cyanobacteria, as a bacteria, have four life phases, starting from the lag phase, log phase, stationary phase and death phase. Lag phase are a phase, where bacteria adapt themselves to stay alive in new environment. Log phase are where bacteria, started to grow, while stationary phase are a phase, when nutritions from environment getting low on numbers. Death phase are phase when there are no more grow, because there are no more or a little number nutrients [12].

\subsection{Temperature and Power of Hydrogen (pH)}

Data on temperature and $\mathrm{pH}$ were recorded from day 0 to day 14 . From day 0 to day 14 , the $\mathrm{pH}$ value are constant on 6 . The environment temperature fluctuation are ranged from $27^{\circ} \mathrm{C}$ to $29^{\circ} \mathrm{C}$, as for Photobioreactors temperature are ranged from $26.5^{\circ} \mathrm{C}$ to $30^{\circ} \mathrm{C}$. Photobioreactors temperature may show a little different value, because of light source heat, that made the inside of Photobioreactors a little bit warm rather than the temperature outside. The place where Photobioreactors taking place too, could affect the value of the temperature, since it does not get sun light.

\subsection{Aeration}

Aeration are a way to agitate or circulate medium, to ensure every microalgae cells gets equal amount of nutrients. Carbon dioxide provide by aeration, affect biomasses growth, mainly on the photosynthetic pathway of microalgae. Carbon dioxide were fixed by rubisco (ribulose biphosphate carboxylase oxygenase) to produce phosphoglycerate. These carbon organic acids are reduced to the sugars and the substrate for starch and oil production. The efficiency of $\mathrm{CO}_{2}$ capture by microalgae, can vary according to algal physiology, nutrients, and temperature. Under optimal conditions, carbon dioxide capture efficiencies as high as $80 \%$ to $99 \%$ [13]. Aeration are also the best methods to encourage the growth of Leptolyngbya HS-16, because the use of manual stirring or regular stirring could damage the cells, due to hydrodynamic stress [14]. Low Intensity of Aeration appear to have a good effects on the growth of the microalgae. The growth curve from both of aeration intensity show increasing trend, but the one from low intensity show more stable growth curve, rather than another one. This could happen because filamentous algae, are usually found in mats-form on calm water surface [4].

\section{Conclusion}

On the previous studies of aeration effect to biomass growth, and another studies, aeration does have effect on encouraging the biomass growth by mixing the nutrients and providing $\mathrm{CO}_{2}$, that take effects on photosynthetic pathways of microalgae. Low Intensity of Aeration have a good effect, since filamentous algae usually forming a mats on calm water surface. Further studies for aeration rates are needed to optimized the photobioreactors systems.

This work was funded by Hibah Publikasi Internasional Terindeks untuk Tugas Akhir Mahasiswa (Hibah PITTA) Tahun Anggaran 2018 to Nining Betawati Prihantini, grant no. 2288/UN2.R3.1/HKP.05.00/2018. 


\section{References}

1. P. Sze. A biology of the algae. 3: 29-30 (2008)

2. J. Komarek, J. Kastovsky, J. Mares, \& J. R. Johans. Taxonomic classification of cyanoprokaryotes (cyanobacterial genera), using a polyphasic approach. Preslia. 86: 305 (2014)

3. A. McGregor \& J. P. Rasmussen. Cyanobacterial composition of microbial mats from an Australian thermal spring: a polyphasic evaluation. FEMS Microb. Ecol. 6(1): 24 (2007)

4. N. B. Prihantini. Polyphasic taxonomy of culturable cyanobacteria isolated from hot springs in west java, Indonesia. Dissertation Department of Biology, Faculty of Mathematics and Natural Sciences, Depok: 115 (2015)

5. J. Singh. \& I. S. Thakur. Evaluation of cyanobacterial endolith Leptolyngbya sp. ISTCY101, for integrated wastewater treatment and biodiese1l production: A toxicological perspective. Alga. Res. 11(4) : 294 (2015)

6. G.E. Fogg, W. D. P. Stewart, P. Fay, \& A. E. Walsby. The Blue-Green Algae. 140 (1973)

7. Y. Pouliot, G. Buelna, C. Racine, J. de la Noüe. Culture of cyanobacteria for tertiary wastewater treatment and biomass production. Biol. Waste. 29: 85 (1989)

8. H. Taher, S. Al-Zuhair, A. Al-Marzouqi. Y. Haik, M. Farid. Growth of microalgae using $\mathrm{CO}_{2}$ enriched air for biodiesel production in supercritical $\mathrm{CO}_{2}$. Renew. Energ. 82: 61 (2015)

9. B. Wang, C. Q. Lan, M. Horsman. Closed photobioreactors for production of microalgal biomasses. Biotech. Adv. 30: 904-912

10. F. Lehr \& C. Posten. Closed photo-bioreactors as tools for biofuel production. Curr. Opin. Biotechnol. 20: $280-285$ (2009)

11. National Institute for Enviromental Studies (=NIES). Media list. Microbial Culture Collection at the National Institute for Environmental Studies (NIES Collection). $\quad 1 \mathrm{hlm}$. http://mcc.nies.go.jp/medium/ja/bg11.pdf : 1 (2001)

12. M.T. Madigan, J.M. Martinko, D.A. Stahl \& D.P. Clark. Biology of Microorganisms. 13 : 125-126 (2012)

13. R. Sayre. Microalgae: The Potential for Carbon Capture. BioScience. 60(9): 724-725 (2010)

14. T.M. Sobzcuk, F.G. Camacho, E.M. Grima \& Y. Christi. Effects of agitation on the microalgae Phaeodactylum tricornutum and Porphyridium cruentum. Bioprocess. Biosyst. Eng. 28: 249 (2006) 